Jurnal Ilmiah "Kreatif" Vol. XII No. 2 Juli 2015

"Iurnal Studi Pemikiran Pendidikan Agama Islam"

\title{
Hubungan Islam dan Politik di Indonesia Serta Implikasinya Terhadap Pendidikan Islam
}

Oleh: Amirullah

\begin{abstract}
Abstrak
Islam tidak bisa dipisahkan dari politik meskipun Islam bukan agama politik. Di Indonesia pertautan antara Islam dan Negara (umat Islam dan kekuasaan) meninggalkan sejarah panjang yang amat melelahkan. Tulisan ini memperlihatkan bahwa kebijakan politik era penjajahan khususnya zaman Belanda sangat diskriminatif dan menyudutkan pendidikan Islam. Pada Orde Lama meskipun dianggap langkah awal bagi perkembangan pendidikan Islam, namun kebijakan pemerintah Orde Lama masih terlihat setengah hati dan kurang menguntungkan pendidikan Islam baik secara kelembagaan maupun kurikulum (mata pelajaran). Hal ini secara tidak langsung merupakan dampak dari hubungan politik umat Islam dan negara (kekuasaan) yang sinis, antagonis dan non kompromi. Tulisan ini menunjukan bahwa pada zaman Orde Baru lah momentum positif bagi eksistensi pendidikan Islam di Indonesia. Kebijakan-kebijakan Pemerintah Orde Baru menjadi babak baru kebangkitan pendidikan Islam di pentas nasional, lahirnya SKB 3 Menteri menjadi awal terintegrasinya pendidikan Islam di dalam sistem pendidikan nasional sehingga berimplikasi pada terjadinya mobilitas sosial dan vertikal siswa-siswa madrasah dan terbukanya peluang anak-anak santri memasuki wilayah pekerjaan pada sektor modern. Hal ini secara tidak langsung merupakan dampak dari hubungaan umat Islam dan negara (kekuasaan) yang bersifat lentur, romantis, inklusif, dan mau berkompromi dengan kekuasaan (negara).
\end{abstract}

Kata Kunci: Islam, Politik, Intelektualisme Baru, Indonesia, Pendidikan Islam

\section{Pendahuluan}

Sejarah manusia sulit untuk dilepaskan dengan sejarah sosial dan politik. Kehidupan sosial merupakan sesuatu yang mutlak bagi makhluk yang bernama manusia. Begitu juga dengan kehidupan politik merupakan bagian dari sisi-sisi kemanusiaan manusia yang tidak mungkin lepas darinya. Dengan kata lain politik hanya untuk manusia dan hanya manusia sajalah yang berpolitik. Sehingga Aristoteles filsuf

\footnotetext{
*Penulis adalah Mahasiswa S2 SPS UIN Syarif Hidayatullah Jakarta. Email:
} amirbem@ymail.com 
Jurnal ITmiah "Kreatif" Vol. XII No. 2 Jufi 2015

"Jurnal Studi Pemikiran Pendidikan Agama Islam"

Yunani pun mengatakan bahwa Manusia adalah Zoon politicon (hewan berpolitik). ${ }^{1}$ Disamping Zoon politicon manusia juga disebutkan Aristoteles sebagai homo sapiens atau homo socius, yang berarti bahwa kehidupan sosial dan politik merupakan sesuatu yang tidak bisa dipisahkan dari diri manusia. Ketika politik dihubungkan dengan Islam yang notabene sebagai agama yang mengajarkan tentang rahmatan lil'alamiin, ajaran universal mengatur kehidupan dunia maupun kehidupan akhirat, tentu mau tidak mau Islam tidak bisa melepaskan dirinya dari kehidupan politik atau juga sebaliknya politik merupakan bagian dari doktrin Islam itu sendiri.

Dari beragam corak pemikiran dalam Islam, khususnya pemikiran politik, tidak ada yang menyangkal bahwa Islam tidak bisa melepaskan dirinya dari yang namanya politik, baik dari dimensi histories maupun dimensi doktrin Islam itu sendiri. Meski demikian diskursus mengenai Islam dan politik tidak berjalan datar tapi terus berkembang menjadi diskursus yang melahirkan banyak khazanah pemikiran yang kemudian melahirkan perdebatan dan juga perbedaan cara memahami hubungan Islam dengan politik, khususnya hubungan Islam dengan negara. Perbedaan ini muncul sesungguhnya lebih pada artikulasi atau interpretasi umat Islam tentang ajaran Islam bukan muncul dari Islam itu sendiri. Termasuk dalam persoalan hubungan Islam dan politik (lebih khusus hubungan Islam dengan negara) di Indonesia. Seperti yang dikatakan Bakhtiar Effendi bahwa hubungan politik antara Islam dan negara-bangsa yang tidak mesra tidak muncul dari doktrin Islam, melainkan bagaimana Islam diartikulasikan secara sosio-cultural, ekonomis, dan politis di Indonesia. ${ }^{2}$

\section{Islam, Politik dan Keindonesiaan}

Dari segi kebahasaan Islam berasal dari bahasa Arab, yaitu dari kata Salima yang mengandung arti selamat, damai, dan sentosa. Dari kata salima kemudian diubah menjadi bentuk aslama yang berarti berserah diri masuk dalam kedamaian, yang juga memiliki arti menyerahkan diri, tunduk, patuh, dan taat. Sementara pengertian Islam dari segi istilah menurut Harun Nasution dengan mengatakan bahwa Islam menurut istilah (Islam sebagai agama) adalah agama yang ajaran-

\footnotetext{
${ }^{1}$ Ayi Sofyan, Etika Politik Islam, (Bandung: Pustaka Setia, 2012), 34.

${ }^{2}$ Bakhtiar Effendi, Islam dan Negara; Transformasi Gagasan dan Praktik Politik Islam di Indonesia, (Jakarta: Demokrasi Project, 2011), 18.
} 
Jurnal Ilmiah "Kreatif" Vol. XII No. 2 Juli 2015

"Iurnal Studi Pemikiran Pendidikan Agama Islam"

ajarannya diwahyukan Tuhan kepada masyarakat manusia melalui Nabi Muhammad Saw. ${ }^{3}$

Untuk melihat Islam lebih jauh lagi M. Atho Mudzhar ${ }^{4}$ mencoba membagi Islam dalam dua corak yang berbeda, yakni Islam sebagai wahyu dan Islam sebagai produk sejarah. Islam sebagai wahyu sebagaimana juga yang didefinisikan oleh Harun Nasution di atas adalah al-aslam wahyun ilahiyun unzila ila nabiyyi Muhammad sallallahu'alaihi wasallama lisa'adati al-dunya wa al-akhirah (Islam adalah wahyu yang diturunkan kepada nabi Muhammad saw sebagai pedoman untuk kebahagiaan hidup di dunia dan akhirat). Berarti Inti Islam adalah wahyu yang diturunkan kepada nabi Muhammad Saw sebagai pedoman untuk kebahagiaan hidup di dunia dan akhirat. ${ }^{5}$ Sementara Islam sebagai produk sejarah Menurut M. Atho Mudzhar bisa dilihat seperti konsep Khulafa al-rasyidin, bangunan Islam klasik, tengah, dan modern adalah produk sejarah. Termasuk juga teologiteologi yang muncul sebagai contoh misalnya teologi syi'ah juga merupakan produk sejarah. Organisasi-organisasi Islam yang banyak bermunculan diberbagai belahan dunia Islam saat ini juga merupakan produk sejarah.

Setelah memberi pengertian Islam secara general. Maka juga perlu kiranya untuk menjelaskan sekilas tentang apa itu politik? Kalau dilihat dari ragam istilahnya, Istilah politik dalam bahasa inggris politic, politik dalam bahasa latin disebut politucus, dalam bahasa Yunani disebut Politicos, berasal dari kata polis yang bermakna city "kota". Sementara politik dalam bahasa Indonesia dipahami dengan tiga arti, yaitu: Pertama, segala urusan dan tindakan (kebijaksanaan, siasat, dan sebagainya) mengenai pemerintahan suatu negara atau terhadap negara lain. Kedua, tipu muslihat atau kelicikan. Ketiga, dipakai nama sebuah disiplin pengetahuan, yaitu Ilmu Politik. ${ }^{6}$ Pada dasarnya Politik adalah usaha mengapai kehidupan yang baik. Dalam istilah Plato dan Aristoteles dinamakan sebagai en dam onia atau the good life. Plato dan Aristoteles menganggap politics sebagai suatu usaha untuk mencapai

\footnotetext{
${ }^{3}$ Lihat Abuddin Nata, Metodelogi Studi Islam, (Jakarta: PT. Rajagrafindo Persada, cetakan ke-20 2013), 63-64.

${ }^{4}$ M. Atho Mudzhar, Pendekatan Studi Islam Dalam Teori dan Praktek, (Yogyakarta: Pustaka Pelajar, cetakan ke-VIII 2011),19-23.

${ }^{5}$ Wahyu itu terdiri atas dua macam: wahyu yang berbentuk Al-Qur'an dan wahyu yang berbentuk hadis, sunnah nabi Muhammad Saw. M. Atho Mudzhar, Pendekatan Studi Islam Dalam Teori dan Praktek, (Yogyakarta: Pustaka Pelajar, cetakan ke-VIII 2011),19.

${ }^{6}$ Lihat Ayi Sofyan, Etika Politik Islam, (Bandung: Pustaka Setia, 2012), $60-61$.
} 
masyarakat politik yang terbaik. Dengan ini manusia menurutnya akan hidup bahagia karena memiliki peluang untuk mengembangkan bakat, bergaul dengan rasa kemasyarakatan yang akrab, dan hidup dalam suasana moralitas yang tinggi. ${ }^{7}$

Sementara dalam Islam sendiri Istilah politik dikenal dengan siyasah. Kata siyasah secara harfiah memiliki arti: pemerintahan, pengambilan keputusan, pembuatan kebijakan, pengurusan, pengawasan, perekayasaan, dan arti lain-lainnya. sementara secara istilah siyasah adalah "pengurusan kemaslahatan umat manusia sesuai dengan syara.", Ibn Abid al-Diin mencoba memberi batasan terkait dengan siyasah, menurutnya: "Siyasah adalah kemaslahatan untuk manusia dengan menunjukkannya kepada jalan yang menyelamatkan, baik di dunia maupun di akhirat. Siyasah berasal daripada Nabi, baik secara khusus maupun secara umum, baik secara lahir maupun secara batin. Segi lahir siyasah berasal dari para pemegang kekuasaan (para sultan dan raja) bukan dari ulama; sedangkan secara batin berasal dari ulama pewaris nabi bukan dari pemegang kekuasaan."9

Definisi-definisi politik di atas pada intinya ingin mengambarkan bahwa Politik itu berkaitan dengan kemahiran, menghimpun kekuatan, meningkatkan kuantitas dan kualitas kekuatan, mengawasi dan menggunakan untuk mencapai tujuan tertentu di dalam negara dan institut lainnya. ${ }^{10}$ karena politik pada akhirnya ingin memenangkan pertarungan untuk merealisasikan tujuan atau cita-cita politik.

Dalam konteks hubungan Islam dan Politik (lebih khusus pertautan antara umat Islam dengan Politik) terdapat Perbedaan pandangan mengenai model politik Islam khususnya hubungan Islam dan negara, Menurut Munawir Sjadzali ${ }^{11}$ paling tidak terdapat tiga

7 Lihat Miriam Budiardjo, Dasar-Dasar Ilmu Politik, (Jakarta: PT Gramedia Pustaka Utama, 2013), 13-14.

${ }^{8}$ Lihat H.A Djazuli, Fiqh Siyasah: Implementasi Kemaslahatan Umat Dalam Rambu-Rambu Syari'ah, (Jakarta: Kencana, 2003), 26.

${ }^{9}$ H.A Djazuli, Fiqh Siyasah: Implementasi Kemaslahatan Umat Dalam Rambu-Rambu Syari'ah, (Jakarta: Kencana, 2003), 27.

${ }^{10}$ Ayi Sofyan, Etika Politik Islam, (Bandung: Pustaka Setia, 2012), 21.

${ }^{11}$ Lebih lengkap lihat Abuddin Nata, Metodologi Studi Islam, (Jakarta: Raja Grafindo Persada, cetakan ke-20, 2013), 322-323. Selanjutnya untuk melihat pemetaan aliran pemikiran di atas yakni Paradigma model pertama dianut oleh intelektual muslim seperti; Abu A'la al Maududi (1903-1979 M), Muhammad Rasyid Ridho (1865-1935 M), Hasan al Bana (1906-1949 M), dan Sayyid Qutub (1906-1966 M). Paradigma model kedua dianut oleh cendekiawan muslim seperti Ahmad Lutfi Sayyid (1872-1963 M), Taha Husayn (1889-1973 M), dan Ali Abd al Raziq (18881966). Sedangkan model ketiga dianut oleh kelompok yang disebut-sebut sebagai kelompok reformis (yang mencoba mensintesa dari pola tradisionalis dan sekularis), 
Jurnal Ilmiah "Kreatif" Vol. XII NNo. 2 Juli 2015

"Jurnal Studi Pemikiran Pendidikan Agama Islam"

aliran di kalangan umat Islam dalam melihat Islam dan politik (ketatanegaraan); Aliran pertama, berpendirian bahwa Islam bukan semata-mata agama dalam pengertian Barat, yakni hanya menyangkut hubungan antara manusia dan tuhan, sebaliknya Islam adalah satu agama yang sempurna dan lengkap dengan pengaturan bagi segala aspek kehidupan manusia termasuk kehidupan bernegara. Aliran Kedua, berpendirian bahwa Islam adalah agama dalam pengertian barat, yang tidak ada hubungannya dengan urusan kenegaraan. Aliran Ketiga, menolak pendapat bahwa Islam adalah suatu agama yang serba lengkap dan bahwa dalam islam terdapat sistem kenegaraan. Tetapi aliran ini juga menolak anggapan bahwa Islam adalah agama dalam pengertian Barat yang hanya mengatur hubungan antara manusia dan maha penciptanya. Aliran ini berpendirian bahwa dalam Islam tidak terdapat sistem ketatanegaraan, tetapi terdapat seperangkat tata nilai etika bagi kehidupan bernegara.

Kalau dilihat juga dari pemetaan Azyumardi Azra terkait pertautan antara umat Islam dan Politik tidak jauh dari gambaran Munawir Sadjali, Azryumardi Azra memperinci lagi dari tiga bentuk tersebut, Pertama, pemisahan antara agama dan politik yang bahkan disertai ideologi politik sekuler yang tidak bersahabat dengan agama (religiously unfriendly-secularism) seperti turki; Kedua, pemisahan yang disertai ideologi yang bersahabat dengan agama (Religiously Friendly Ideology), seperti Indonesia. Bisa juga disebut sebagai bentuk akomodasi antara negara dan agama; Ketiga, penyatuan agama dengan negara seperti Arab Saudi, yang dapat juga disebut sebagai teokrasi. ${ }^{12}$

Berdasarkan klasifikasi di atas secara umum Indonesia dalam hubungan Islam dan politik, berada pada poin kedua yaitu pemisahan yang disertai ideologi yang bersahabat dengan agama (religiously Friendly Ideology). Artinya falsafah dan prinsip bernegara yang terkandung dalam Pancasila dan UUD 1945 sampai dengan turunannyalah yang menjadi dasar kehidupan berbangsa dan bernegara di Negara Kesatuan Republik Indonesia. Walau demikian secara teoritis ketiga aliran pemikiran politik Islam di atas dalam sejarahnya meninggalkan perseteruan secara radikal dan hingga saat ini terus

diantaranya adalah Muhammad Husayn Haikal (1888-1956 M). Selengkapnya Lihat Ismail Marzuki, Ideologi \& Politik Hukum Islam; Kajian Partai Politik PKS, (Jakarta: PUSTIKOM, 2012), 8.

${ }^{12}$ Lihat Azyumardi Azra, Islam dan Konsep Negara; Pergulatan Politik Indonesia Pasca-Soeharto, dalam buku fikih kebinekaan; pandangan Islam Indonesia Tentang Umat, Kewargaan, dan Kepemimpinan Non-Muslim, (Bandung: Mizan, 2015),115. 
Jurnal ITmiah "Kreatif" Vol. XII No. 2 Jufi 2015

"Iurnal Studi Pemikiran Pendidikan Agama Islam"

berdinamika walaupun di Indonesia aliran yang pertama dan kedua sumbunya sangat kecil jikapun itu ada.

\section{Islam dan Politik di Indonesia dari Hubungan Sinis ke Romantis- Inklusif}

Pada zaman Orde Lama hubungan Islam dan negara bisa disebut sebagai hubungan yang sinis tanpa kompromi. Hal ini memunculkan Polemik serius dikalangan para tokoh, baik yang umumnya dikenal sebagai aktivis Islam (santri) dengan aktivis nasionalis (abangan). ${ }^{13}$ Aktivis Islam (kaum santri) direpresentasikan oleh Muhammad Natsir, Agus Salim dan lain-lain. Sementara di pihak aktivis nasionalis (kaum abangan) direpresentasikan oleh Soekarno, Muhammad Hatta dan lainlain. Perdebatan-perdebatan yang cukup serius pada tahun 1945 di awal kemerdekaan dan juga perdebatan-perdebatan Majelis Konstituante mengenai masa depan konstitusi negara pada tahun 1950 antara dua kelompok yang memperjuangkan Islam sebagai dasar negara dengan pihak nasionalis yang mengusung pancasila dan mempertahankannya sebagai dasar negara melahirkan sikap kecurigaan dan sinis di antara mereka. Seperti yang dikatakan Bachtiar Effendy bahwa Hubungan politik antara Islam dan negara di Indonesia pada sebagian besar babakan sejarahnya adalah kisah antagonisme dan kecurigaan satu sama lain. $^{14}$

Muhammad Natsir memperkenalkan gagasan kebangsaan Islam. Natsir mengkhawatirkan bergulirnya gagasan nasionalisme Soekarno menjadi suatu bentuk 'ashabiyah baru. Gagasan itu, dalam pandangannya, dapat mengandung fanatisme yang kemudian memutuskan tali ukhuwwah yang mengikat seluruh kaum Muslimin dari berbagai bangsa." Bagi Natsir, gagasan nasionalisme harus mempunyai sejenis landasan teologis. Natsir juga percaya bahwa nasionalisme

13 Mengomentari antara kelompok Islam dan kelompok nasionalis sebagaimana kategorisasi kelompok santri (muslim yang taat) dan kelompok abangan (muslim yang tidak taat) menurut Bakhtiar Effendy, kategorisasi di atas menurutnya tidaklah terletak pada tingkat ketaatan religius (atau keimanan) mereka, melainkan pada cara mereka menafsirkan dan memahami ajaran- ajaran Islam. Karena itu, meskipun harus menolak gagasan negara Islam, orang orang seperti Soekarno dan Hatta tidaklah kurang Islam dibandingkan rekan-rekan mereka sesama Muslim yang berusaha keras untuk mendirikan negara Islam. Syafii Maarif juga menyebutkan bahwa Hatta adalah seorang muslim yang taat. Lihat Ahmad Syafii Maarif, Islam Dalam Bingkai Keindonesiaan dan Kemanusiaan, (Bandung: Mizan, 2009), 24.

${ }^{14}$ Lebih lanjut lihat Bakhtiar Effendi, Islam dan Negara; Transformasi Gagasan dan Praktik Politik Islam di Indonesia, (Jakarta: Demokrasi Project, 2011), 66. 
Jurnal ITmiah "Kreatif" Vol. XII No. 2 Juli 2015

"Iurnal Studi Pemikiran Pendidikan Agama Islam"

Indonesia harus berwatak Islami. Dalam konteks ini Natsir menulis sebagaimana dikutip Bachtiar Effendy: "Pergerakan Islamlah (yakni SI) yang lebih dulu membuka jalan medan politik kemerdekaan di tanah ini, yang mula-mula menanamkan bibit persatuan Indonesia yang menyingkirkan sifat kepulauan dan keprovinsian, yang mula-mula menanam persaudaraan dengan kaum yang sama senasib di luar batas Indonesia dengan tali ke-Islaman." 15

Tidak berhenti disitu saja, perseteruan ideologis antara kelompok Islam dan kelompok nasionalis berlangsung secara penuh dalam pertemuan-pertemuan BPUPKI, yang dilaksanakan antara akhir Mei hingga pertengahan Agustus 1945. Seraya menegaskan kembali alur penalaran teologis dan sosiologis sebelumnya, kelompok yang pertama menyatakan bahwa Indonesia harus menjadi sebuah negara Islam, atau Islam harus menjadi dasar ideologis negara. ${ }^{16}$ Sedang kelompok yang kedua, seperti Soekarno, Muhammad Hatta dan Supomo, mengusulkan dibentuknya sebuah negara kesatuan nasional di mana masalah-masalah negara harus dipisahkan dari masalah-masalah agama. ${ }^{17}$ Perseteruan ini berakhir dengan dijebloskannya beberapa pimpinan masyumi ke penjara seperti Muhammad Natsir dan Syafruddin Prawiranegara oleh Soekarno karena dianggap melawan negara dan kemudian berakhir dengan di bekukanya Partai Masyumi oleh Soekarno pada Tahun 1960. ${ }^{18}$

Berbeda dengan Zaman Orde Baru, generasi yang muncul di era ini agaknya bersifat lentur, romantis, ingklusif, dan mau berkompromi dengan kekuasaan (negara). Hubungan yang radikal antara Islam dan negara di zaman Orde Lama mulai diubah dengan gagasan yang lebih substantif. Mereka bisa dikatakan sebagai intelektualisme Islam Era Orde Baru atau dalam istilah Bachtiar Effendy disebut "generasi intelektual Islam baru/intelektualisme Islam baru" dan oleh M. Syafi'i Anwar menyebutnya para "Santri Baru" memperlihatkan corak

15 Bakhtiar Effendy, Islam dan Negara; Transformasi Gagasan dan Praktik Politik Islam di Indonesia, (Jakarta: Demokrasi Project, 2011), 81-82.

${ }^{16}$ Paling tidak ada tiga argumen yang paling mendasar mengenai gagasan mendirikan negara Islam; Pertama, watak holistik Islam. Kedua, keunggulan Islam atas semua ideologi dunia lain, dan Ketiga, kenyataan bahwa Islam dipeluk oleh mayoritas warga negara Indonesia.

17 Bakhtiar Effendy, Islam dan Negara; Transformasi Gagasan dan Praktik Politik Islam di Indonesia, (Jakarta: Demokrasi Project, 2011), 99-100.

18 Bakhtiar Effendy, Islam dan Negara; Transformasi Gagasan dan Praktik Politik Islam di Indonesia, (Jakarta: Demokrasi Project, 2011), 147. Untuk paparan lebih lengkap mengenai perdebatan para aktivis Islam dan nasionalis, lihat Robert W. Hefner, Civil Islam; Islam dan Demokratisasi di Indonesia, (Yogyakarta: ISAI, 2001). 
pemikiran politik Islam yang berbeda dengan era pra kemerdekaan dan pasca kemerdekaan (orde lama).

Menurut M. Syafi'i Anwar pemikiran politik cendekiawan muslim di era Orde Baru dapat ditipologikan menjadi 5 corak pemikiranrespon-sikap dari mereka yaitu, formalistik, substantivistik, transformatik, totalistik, idealistik, dan realistik. ${ }^{19}$ Corak pemikiran yang formalistik lebih pada mengutamakan peneguhan dan ketaatan yang ketat pada format-format ajaran Islam. corak berpikir formalistik dalam politik lebih menekankan pada ideologisasi dan politisasi yang mengarah pada simbolisme keagamaan secara formal. Terminologi politik menurut cara pandang ini bahwa doktrin tauhid diterjemahkan bukan sekedar rumusan teologis, tetapi juga suatu sistem keimanan dan tindakan politik yang komprehensif dan eksklusif. Selanjutnya pemikiran politik yang bersifat Substantivistik lebih memaknai substansi atau makna iman dan peribadatan lebih penting daripada formalitas dan simbolisme keberagamaan serta ketaatan yang bersifat literal kepada wahyu Tuhan. Selanjutnya Pemikiran transformatik lebih bersifat praksis. Perhatian utamanya bukanlah pada aspek-aspek doktrinal dari teologi Islam, tetapi lebih fokus pada pemecahan masalah-masalah empiris dalam bidang sosial-ekonomi, pengembangan masyarakat, penyadaran hak-hak politik rakyat, orientasi keadilan sosial dan sebagainnya. Pemikiran transformatik bertolak dari pandangan dasar bahwa misi Islam yang utama adalah kemanusiaan. bagaimana membumikan ajaran-ajaran Islam agar bisa menjadi kekuatan yang membebaskan manusia dan masyarakat dari belenggu ketidakadilan, kebodohan, dan keterbelakangan.

Selanjutnya pemikiran totalistik berbasis pada pemahaman bahwa doktrin Islam bersifat total (kaffah), meliputi semua bidang kehidupan sosial, politik, ekonomi, serta melingkupi segi-segi baik individual, kolektif, maupun masyarakat kemanusiaan umumnya. Dengan kata lain bahwa Al-Qur'an dan hadits telah lengkap mengatur kehidupan umat manusia. makanya menurut pandangan ini satu-satunya cara untuk menyelamatkan manusia dan masyarakat dari kehancuran adalah dengan melaksanakan ajaran Al-qur'an dan sunnah secara totalitas. Selanjutnya pemikiran idealistik yang bertolak dari pandangan pentingnya perjuangan umat untuk berorientasi pada tahapan menuju "Islam cita-cita" (ideal Islam). Islam cita-cita adalah Islam sebagaimana

${ }^{19}$ Tipologi yang dibuat oleh M. Syafi'i Anwar di atas tidak semata-mata mendasarkan pada aliran pemikiran yang dianut oleh masing-masing cendekiawan. Tetapi juga mengamati kerangka teoritis atau pendekatan yang digunakannya. Lebih lanjut lihat M. Syafi'i Anwar, Pemikiran dan Aksi Islam Indonesia; Sebuah Kajian Politik tentang cendekiawan muslim orde baru, (Jakarta: Paramadina, 1995),143-184. 
Jurnal Ilmiah "Kreatif" Vol. XII No. 2 Juli 2015

"Jurnal Studi Pemikiran Pendidikan Agama Islam"

yang tersurat dan tersirat dalam Al-Qur'an dan sunnah yang otentik, tetapi yang belum tentu tercermin dalam tingkahlaku sosio-politik umat Islam dalam realitas sejarah mereka. Bagi pemikir idealistik Perumusan Islam cita-cita dimaksudkan untuk membedakan dengan "Islam sejarah" (historic Islam). Islam cita-cita dianggap sebagai kekuatan penggerak (driving force) dari seluruh gerakan Islam, baik itu politik, sosial, maupun kultural. Sumber utama dari Islam cita-cita adalah cita-cita etik dan moral Al-qur'an, yang dipahami secara cerdas dan kontekstual sesuai dengan dinamika dan perubahan zaman. Dan terakhir adalah pemikiran realistik, cara pandang ini melihat keterkaitan atau melakukan penghadapan antara dimensi substantif dari ajaran atau doktrin agama, dengan konteks sosio-kultural masyarakat pemeluknya. Bagi pemikir realistik, Islam sebagai agama wahyu yang universal, perlu hadir dan menampakkan diri secara realistis dalam keragaman, yang diwarnai oleh perjalanan sejarah dan situasi sosial kultural umat pemeluknya. ${ }^{20}$

Meskipun ada tipologisasi seperti di atas, tapi sesungguhnya generasi intelektual era Orde Baru sama-sama menerima pancasila dan UUD 1945 sebagai dasar negara. Dengan sebuah paradigma bahwa Indonesia bukan negara agama, bukan pula negara yang mengakui adanya salahsatu agama resmi, dan tentu saja bukan negara sekuler. Indonesia adalah berdasarkan Pancasila dimana semua agama dan masing-masing pemeluknya diperlakukan sama sebagai warga negara Indonesia. ${ }^{21}$ Sehingga perjuangan intelektualisme Islam baru tidak lagi mempermasalahkan dasar negara, tapi mereka lebih fokus kepada isu-isu tentang kesejahteraan sosial, pemerataan-pembangunan ekonomi, isu-isu pendidikan, dan pengembangan lebih jauh gagasan tentang penguatan tatanan politik yang lebih egalitarian. Tokoh-tokoh generasi intelektual Islam baru inilah yang membawa corak baru model politik Islam di Indonesia. ${ }^{22}$ Disamping itu Sikap dan pandangan politik mereka yang nonkonfrotatif dianggap berhasil dan mendapat tempat di hati penguasa dan juga publik, meskipun ada banyak yang menolaknya.

${ }^{20}$ M. Syafi'i Anwar, Pemikiran dan Aksi Islam Indonesia; Sebuah Kajian Politik tentang cendekiawan muslim orde baru, (Jakarta: Paramadina, 1995),143-184.

${ }_{21}$ Nasaruddin Umar, "Antara Negara dan Agama Negara," lihat di www.depag.co.id, 4.

22 Bakhtiar Effendy, Islam dan Negara; Transformasi Gagasan dan Praktik Politik Islam di Indonesia, (Jakarta: Demokrasi Project, 2011), 238. 
Jurnal Ilmiah "Kreatif" Vol. XII No. 2 Juli 2015

"Iurnal Studi Pemikiran Pendidikan Agama Islam"

\section{Dampak Kebijakan Politik di Indonesia bagi Eksistensi Pendidikan Islam}

Hadirnya pendidikan Islam di Indonesia bersamaan dengan kehadiran Islam di Indonesia. Islam yang kental dengan ajaran edukasi melalui budaya membaca dan tulis, sejak awal diwujudkan lewat pengajian, halaqah, dan lainnya menjadikan aktifitas pendidikan berlangsung di masjid, di rumah-rumah, surau, pesantren dan lain-lain. Tapi secara khusus disebut-sebut pendidikan Islam di Indonesia telah dimulai pada awal abad XX M hingga dewasa ini merupakan perjalanan yang cukup panjang. Dimana perkembangan cukup draktis terjadi pada masa orde lama dan terus mendapat momentum positifnya pada masa orde baru.

\section{Zaman Penjajahan}

Kebijakan pemerintah Hindia Belanda dalam hubungannya dengan pendidikan agama adalah bersifat netral, ini dinyatakan dalam pasal 179 (2) I.S (Indische Staatsregeling) bahwa pengajaran itu diberikan dengan menghormati keyakinan agama masing-masing. Pengajaran agama hanya boleh berlaku di luar jam sekolah. Di zaman pemerintah Belanda sekolah-sekolah yang dibangun sangat terbatas, misalnya pada tahun 1907 atas perintah gubernur jenderal van heutz didirikanlah sekolah-sekolah desa. Pada awal abad 20 bermuncullah sekolah kelas satu, sekolah kelas dua, sekolah desa (volksschool), europese lagere school (ELS), Holland chinese school (HCS), Hollands Inlandse school (HIS), Meer Uitgebreid Lager Ounderwijs (MULO), Hogere Burgerscholl (HBS), Algemen Middelbare School (AMS), dan lain sebagainya. ${ }^{23}$ Namun sekolah yang didirikan belanda tersebut belum mampu menampung populasi penduduk Indonesia ditambah pula dengan tingkat penghasilan ekonomi masyarakat Indonesia yang rendah. Sehingga satu-satunya alternatif lain dari lembaga pendidikan yang merakyat adalah dan egaliterian adalah pendidikan pesantren dan surau.

Antara kedua lembaga di atas yakni sekolah yang dikelola Belanda dan Pesantren dan Surau yang dikelola umat Islam berjalan terpisah, masing-masing berjalan sendiri-sendiri. Sehingga muncullah perbedaan yang tajam antara ilmu agama dan ilmu umum, maka muncul pula sistem pendidikan umum dan sistem pendidikan agama pada fase terakhir abad ke-19, serta dilanjutkan dan diperkuat pada abad 20. Dalam konteks ini muncullah dikotomisasi antara

${ }^{23}$ Selengkapnya lihat Haedar Putra Daulay, Sejarah Pertumbuhan dan Pembaruan Pendidikan Islam di Indonesia, (Jakarta: Kencana Prenada Group, 2007), 29-30. 
Jurnal ITmiah "Kreatif" Vol. XII No. 2 Jufi 2015

"Jurnal Studi Pemikiran Pendidikan Agama Islam"

pendidikan Islam dengan sekolah yang didirikan Belanda secara mengangga. Tidak hanya itu, pada zaman Belanda pendidikan Islam terlihat sangat dipojokan dan sering mendapat perlakuan diskriminatif.

Kebijakan-kebijakan diskriminatif Pemerintah Hindia Belanda terhadap pendidikan Islam selanjutnya terlihat dari peraturan-peraturan guna membatasi dan mengawasi kegiatan umat Islam, seperti ordonasi guru tahun 1905, yakni yang mewajibkan minta izin bagi guru-guru agama, begitu juga dengan pemberian dana bantuan sangat bersifat diskriminatif. ${ }^{24}$

Sikap diskriminasi Belanda terhadap Pendidikan Islam (bangsa pribumi) di antaranya diskriminasi sosial, diskriminasi ras, diskriminasi anggaran, dan diskriminasi dalam hal kepemelukan agama. $^{25}$ Meski demikian respon umat Islam terhadap sikap diskriminatif tersebut bersifat progresif. Di mana usaha umat Islam mencapai kesetaraan dan kesejajaran baik dari segi kelembagaan maupun kurikulum terus dilakukan. Tanpa disadari masuknya penjajahan belanda yang membawa sistem pendidikan Barat yang dianggap sekuler itu telah membuka mata bahkan mendorong umat Islam Indonesia, akan adanya sistem school yang memberi pengajaran pengetahuan umum (membaca, menulis, berhitung, ilmu bumi, ilmu hayat, sejarah dan lain-lain). ${ }^{26}$

\section{Orde Lama}

Perkembangan pendidikan Islam pada masa orde lama mendapat angin segar ${ }^{27}$ dan sangat terkait dengan peran Departemen Agama yang mulai resmi berdiri pada tanggal 3 Januari 1946.

${ }^{24}$ Sebagai contoh pada tahun 1928 , kebijakan berat sebelah terlihat pada saat pemberian bantuan untuk kristen berjumlah f.1.666.300, sedangkan untuk Islam hanya berjumlah f.3.950. selengkapnya lihat Haedar Putra Daulay, Sejarah Pertumbuhan dan Pembaruan Pendidikan Islam di Indonesia, (Jakarta: Kencana Prenada Group, 2007), 33-34.

25 Selengkapnya lihat Abuddin Nata, Kapita Selekta Pendidikan Islam, (Bandung: Angkasa, 2003), 16-22.

${ }^{26}$ Lihat Husni Rahim, Madrasah Dalam Politik Pendidikan Islam, (Jakarta: Logos Wacana Ilmu, 2005)

27 Setelah Indonesia merdeka, pendidikan agama telah mendapat perhatian positif dari pemerintah, baik di sekolah negeri maupun swasta. Usaha tersebut dimulai dengan memberikan bantuan sebagaimana anjuran oleh Badan Pekerja Komite Nasional Pusat (BPKNP) tanggal 27 Desember 1945, disebutkan : "Madrasah dan pesantren yang pada hakikatnya adalah satu sumber pendidikan dan pencerdasan rakyat jelata yang telah berurat dan berakar dalam masyarakat Indonesia pada umumnya, hendaknya mendapatkan perhatian dan bantuan nyata berupa tuntunan dan bantuan material dari pemerintah" 
Departemen Agama sebagai suatu lembaga pada masa itu, secara intensif memperjuangkan politik pendidikan Islam di Indonesia. Pendidikan Islam pada masa itu ditangani oleh suatu bagian khusus yang mengurus masalah pendidikan agama, yaitu Bagian Pendidikan Agama. Tugas dari bagian tersebut sesuai dengan salah satu nota Islamic education in Indonesia yang disusun oleh Bagian Pendidikan Departemen Agama pada tanggal 1 September 1956, yaitu : 1) memberi pengajaran agama di sekolah negeri dan partikulir, 2) memberi pengetahuan umum di madrasah, dan 3)mengadakan Pendidikan Guru Agama serta Pendidikan Hakim Islam Negeri. $^{28}$

Secara kelembagaan kebijakan pemerintah Orde Lama terhadap Pendidikan Islam bisa dikatakan positif jika dibandingkan pada pra kemerdekaan. Kebijakan memberikan fasilitas dan sumbangan materil terhadap lembaga-lembaga pendidikan Islam. setelah beberapa waktu sebelumnya sempat dikucilkan oleh Pemerintah Belanda. Kesempatan tersebut digunakan oleh umat Islam Indonesia untuk mendirikan lembaga-lembaga pendidikan Islam. sehingga pada Tahun 1945 terdapat 13.849 madrasah 2.017 murid di Indonesia. Di samping itu didirikan dan dikembangkannya juga Pendidikan Guru Agama (PGA) dan Pendidikan Hakim Islam Negeri. Kedua madrasah ini menandai perkembangan yang sangat penting dimana madrasah dimaksudkan mencetak tenaga-tenaga profesional keagamaan, di samping mempersiapkan tenaga-tenaga yang siap mengembangkan madrasah. Sehingga pertengahan dekade 60-an dilaporkan bahwa jumlah madrasah tingkat rendah sudah mencapai 13. 057. 776, buah Madrasah Tsanawiyah dan 1.188 Madrasah Aliyah. ${ }^{29}$

Namun demikian penting untuk dilihat secara kritis Kebijakan-kebijakan penting pemerintah Orde Lama menyangkut pendidikan Islam antara lain; lahirnya UU Pendidikan tahun 1950 No. 4, dan UU Pendidikan tahun 1954 No.20 yang isinya agak kurang menguntungkan bagi pengembangan pendidikan Islam. diantaranya adalah sekolah negeri diselenggarakan pelajaran agama; orang tua murid menetapkan apakah anaknya mengikuti pelajaran

\footnotetext{
28 Lihat Maksum, Madrasah Sejarah dan Perkembangannya, (Jakarta: PT. Logos Wacana Ilmu, 1999), 123-124. Lihat juga http://pendis.kemenag.go.id diakses pada 22 Desember 2015.

29 Lihat juga Abuddin Nata, Kapita Selekta Pendidikan Islam, (Bandung: Angkasa, 2003), 36-37. Lebih lengkap baca juga Mahmud Yunus, Sejarah Pendidikan Islam di Indonesia, (Jakarta: PT Mahmud Yunus, cetakan ketiga 2008).
} 
tersebut, pelajaran agama tidak mempengaruhi kenaikan kelas. ${ }^{30}$ Meski pelajaran agama diajarkan di sekolah negeri tapi bukan sebagai faktor penting seperti mata pelajaran lainnya. sangat ditentukan oleh orangtua murid dan termasuk tidak mempengaruhi kenaikan kelas.

Era ini memang menjadi babak baru kesadaran bangkitnya pendidikan Islam dengan berdirinya Departemen Agama. Namun demikian secara politik kebijakan-kebijakan Pemerintah Orde Lama masih kurang menguntungkan pendidikan Islam baik secara kelembagaan maupun kurikulum (mata pelajaran).

\section{Orde Baru}

Sejak dibubarkan PKI dengan G30S/PKI pada tanggal 30 Oktober 1965, bangsa Indonesia telah memasuki masa "Orde Baru." Perkembangan pendidikan Islam selanjutnya pada masa orde baru dimulai dari kebijakan pada pasal 4 TAP MPRS No.XXVII/MPRS/1966 yang memuat kebijakan tentang isi pendidikan. Untuk mencapai dasar dan tujuan pendidikan, maka isi pendidikan adalah : (1) Mempertinggi mental, moral, budi pekerti dan memperkuat keyakinan beragama. (2) Mempertinggi kecerdasan dan keterampilan. (3) Membina dan mengembangkan fisik yang kuat dan sehat. ${ }^{31}$

Kebijakan pemerintah Orde Baru mengenai pendidikan agama-Islam, termasuk madrasah, bersifat positif dan konstruktif, khususnya dalam dua dekade terakhir 1980-an - 1990-an. Komitmen pemerintah Orde Baru untuk menyelenggarakan pendidikan agama sebagai bagian yang tidak terpisahkan dari sistem Pendidikan Nasional. ${ }^{32}$ Pada tahun 1972 pemerintah Indonesia dengan gencarnya mewacanakan untuk menyatukan lembaga-lembaga pendidikan di Indonesia termasuk madrasah beralih menjadi di bawah Departemen Pendidikan dan Kebudayaan (P\&K). Wacana-wacana itu kemudian menjadi nyata dengan dikeluarkannya Keputusan Presiden (Kepres) Nomor 34/19/1972, yang menyatakan bahwa semua lembaga

30 Lihat Maksum, Madrasah Sejarah dan Perkembangannya, (Jakarta: PT. Logos Wacana Ilmu, 1999). Lihat juga Abuddin Nata, Kapita Selekta Pendidikan Islam, (Bandung: Angkasa, 2003), 28-38. Baca juga Syamsul Nizar dan Muhammad Syaifuddin, Isu-Isu Kontemporer Tentang Pendidikan Islam, (Jakarta: Kalam Mulia, 2010), 37-40.

${ }^{31}$ Lihat http://pendis.kemenag.go.id/ "Sejarah Pendidikan Islam" diakses 22 Desember 2015.

32 Lihat Maksum, Madrasah Sejarah dan Perkembangannya, (Jakarta: PT. Logos Wacana Ilmu, 1999), 131. 
pendidikan di Indonesia berada di bawah tanggung jawab Departemen P \& K, termasuk lembaga pendidikan agama. Walaupun Kepres itu tidak terlaksana hingga Tahun 1974 presiden Soeharto kembali memaksakan supaya kepres 34/1972 itu untuk segera dilaksanakan dengan dikeluarkannya Inpres (Instruksi Presiden) Nomor 15/1974. Tapi pada akhirnya rencana menyatukan semua lembaga pendidikan di bawah $\mathrm{P} \& \mathrm{~K}$ tidak terwujud karena mendapat pertentangan dari para praktisi pendidikan Islam dan ulama yang mengkhawatirkan dengan kebijakan itu bisa menghilangkan identitas pendidikan Islam. ${ }^{33}$

Jika dilihat lebih jauh mengenai SKB 3 Menteri yang pada sidang Kabinet Terbatas 26 Nov 1974, Menteri Agama RI menyampaikan kecemasan umat Islam berkaitan dengan isi dan implikasi lebih jauh dari Keppres dan Inpres. Presiden memberi perhatian terhadap masalah tersebut, dan mengeluarkan petunjuk pelaksanaan Keppres No. 34 tahun 1972 dan Inpres No. 15 Tahun 1974, yang isinya : Pertama, Pembinaan pendidikan umum adalah tanggung jawab Menteri Pendidikan dan kebudayaan, sedangkan tanggung jawab Pendidikan Agama menjadi tanggung jawab Menteri Agama. Kedua, Untuk pelaksanaan Keppres No. 34 tahun 1972 dan Inpres No. 15 tahun 1974 dengan sebaik-baiknya perlu ada kerjasama antara Departemen P\&K, Departemen Dalam Negeri dan Departemen Agama.

Kebijakan Pemerintah Orde Baru melalui SKB 3 Menteri memiliki makna. Pertama, terjadinya MOBILITAS sosial dan vertikal siswa-siswa madrasah. kedua, terbukanya peluang anakanak santri memasuki wilayah pekerjaan pada sektor modern. ${ }^{34}$ Sehingga pendidikan Islam tidak terpojokan dan terdiskriminasi sebagaiman era sebelumnya.

Secara langsung maupun tidak langsung bahwa kebijakankebijakan pemerintah Orde Baru yang menguntungkan umat Islam khususnya pengakuan dan peningkatan kualitas pendidikan Islam merupakan implikasi dari hubungan politik umat Islam dan negara

${ }^{33}$ Maksum, Madrasah Sejarah..., viii-xi.

34 Selengkapnya lihat Maksum, Madrasah Sejarah dan Perkembangannya, (Jakarta: PT. Logos Wacana Ilmu, 1999). Lihat Syamsul Nizar dan Muhammad Syaifuddin, Isu-Isu Kontemporer Tentang Pendidikan Islam, (Jakarta: Kalam Mulia, 2010), 40-44. Lihat Haedar Putra Daulay, Sejarah Pertumbuhan dan Pembaruan Pendidikan Islam di Indonesia, (Jakarta: Kencana Prenada Group, 2007), lihat Abuddin Nata, Kapita Selekta Pendidikan Islam, (Bandung: Angkasa, 2003), 4654. Selengkapnya Baca juga Mahmud Yunus, Sejarah Pendidikan Islam di Indonesia, (Jakarta: PT Mahmud Yunus, cetakan ketiga 2008). 
Jurnal Ilmiah "Kreatif" Vol. XII No. 2 Juli 2015

"Iurnal Studi Pemikiran Pendidikan Agama Islam"

(kekuasaan) yang bersifat produktif, romantis, dan berkompromi. Berbeda dengan zaman Orde Lama yang dalam babak sejarahnya banyak dihabiskan dengan sikap antagonisme, sinisme dan tanpa kompromi. Artinya tidak bisa dipungkiri bahwa munculnya generasi intelektualisme baru sebagaimana dijelaskan sebelumnya di atas telah membawa wajah baru hubungan umat Islam (Islam) dengan negara (kekuasaan). sehingga berdampak pada kebijakan pendidikan Islam yang tidak sedikit sangat menguntungkan umat Islam.

Jika dilihat tidak hanya itu, ternyata dampak dari model baru politik Islam (hubunga Islam dan negara) yang dipelopori oleh para intelektualisme Islam baru memunculkan kebangkitan Islam di ranah publik dan juga di jantung-jantung kekuasaan. Seperti yang disebutkan oleh Robert W. Hefner bahwa pada akhir tahun 1970-an dan 1980-an, Indonesia mengalami kebangkitan Islam yang secara historis belum pernah terjadi sebelumnya. Hefner melaporkan bahwa terjadi peningkatan yang signifikan dalam pembangunan masjid, shalat jum'at, pendidikan agama, pengumpulan zakat, dan naik haji ke mekkah. ${ }^{35}$ Disamping itu pemerintah melakukan politik merangkul dikalangan intelektual Islam (umat Islam). Dimana umat Islam dibukakan pintu oleh pemerintah untuk mengisi kekuasaan. Jika dilihat bahwa Sebelum tahun 1990-an atau selama dua dasawarsa awal kepemimpina Soeharto umat Islam nyaris tidak pernah diikutkan dalam pembagian kekuasaan. Soeharto lebih suka bekerja sama dengan golongan minoritas terdiri dari kristen, katolik, dan kelompok etnis cina dengan dukungan militer dan golkar sebagai mesin politiknya. Namun, kemudian pada awal 1990-an, Seoharto melakukan perubahan kebijakan dengan mengajak serta kelompok Islam untuk masuk ke panggung kekuasaan. pada saat itulah kelompok Islam dengan cepat menguasai jajaran birokrasi. Tentu hal ini memberi dampak pada gerakan islamisasi birokrasi tidak hanya di pusatpusat kekuasaan di Jakarta, tetapi juga di daerah-daerah. Dimana posisiposisi yang dikuasai kelompok kristen dan katolik, dari waktu ke waktu diambilalih oleh kelompok Islam. ${ }^{36}$

35 Lebih lengkap lihat Robert W. Hefner, Civil Islam; Islam dan Demokratisasi di Indonesia, (Yogyakarta: ISAI, 2001), 40.

${ }^{36}$ Jajang Jahroni, Ketika Nasionalisme Membusuk, Journal Studi Islamika Indonesia, Volume 12, Number 3, 2005, 581. 
Jurnal Ilmiah "Kreatif" Vol. XII No. 2 Juli 2015

"Jurnal Studi Pemikiran Pendidikan Agama Islam"

\section{Simpulan}

Perkembangan Pendidikan Islam di Indonesia tidak bisa dipisahkan dengan pertautan antara umat Islam dan negara (kekuasaan). hubungan Islam dan Politik (negara) sejak zaman penjajahan hingga sekarang telah berimplikasi terhadap eksistensi pendidikan Islam. Lepas dari kelebihan dan kekuarangan dari setiap fase sejarah tersebut tapi bisa dikatakan bahwa Era Orde Barulah pendidikan Islam berkembang secara positif di mana pendidikan Islam terintegrasi di dalam pendidikan Nasional. Hal ini tentu saja karena dampak dari hubungan umat Islam dan negara yang produktif-subtantif-progresif.

\section{Daftar Pustaka}

Adonis. Arkeologi Sejarah-Pemikiran Arab-Islam. Yogyakarta: Lkis Pelangi Aksara, 2007.

Atho Mudzhar, M. Pendekatan Studi Islam Dalam Teori dan Praktek. Yogyakarta: Pustaka Pelajar, cetakan ke-VIII 2011.

Azra, Azyumardi. Revitalisasi Islam Politik dan Islam Kultural di Indonesia. Jurnal Indo-Islamika Volume 1, Nomor 2, Tahun 2012.

Budiardjo, Miriam. Dasar-Dasar Ilmu Politik. Jakarta: Gramedia Pustaka Utama, 2013.

Djazuli, H.A. Fiqh Siyasah: Implementasi Kemaslahatan Umat Dalam Rambu-Rambu Syari'ah. Jakarta: Kencana, 2003.

Daulay, Haedar Putra, Sejarah Pertumbuhan dan Pembaruan Pendidikan Islam di Indonesia, Jakarta: Kencana Prenada Group, 2007.

Effendy, Bakhtiar. Islam dan Negara; Transformasi Gagasan dan Praktik Politik Islam di Indonesia. Jakarta: Demokrasi Project, 2011.

H. Hart, Michael. Seratus Tokoh Yang Paling Berpengaruh Dalam Sejarah, Jakarta: PT. Dunia Pustaka Jaya, 1982.

Jahroni, Jajang. "Ketika Nasionalisme Membusuk." Journal Studi Islamika Indonesia, Volume 12, Number 3, 2005.

Maksum, Madrasah Sejarah dan Perkembangannya, Jakarta: Logos Wacana Ilmu, 1999.

Marzuki, Ismail. Ideologi \& Politik Hukum Islam; Kajian Partai Politik PKS. Jakarta: PUSTIKOM, 2012.

Nasution, Harun. Akal dan Wahyu Dalam Islam. Jakarta: Universitas Indonesia Press, 2011. 
Jurnal ITmiah "Kreatif" Vol. XII No. 2 Jufi 2015

"Jurnal Studi Pemißiran Pendidikan Agama Islam"

Nata, Abuddin. Metodelogi Studi Islam. Jakarta: PT. Raja Grafindo Persada, 2013.

Nizar, Syamsul dan Syaifuddin, Muhammad, Isu-Isu Kontemporer Tentang Pendidikan Islam, Jakarta: Kalam Mulia, 2010.

Rais, Amien. Tauhid Sosial: Formula Menggempur Kesenjangan. Bandung: Mizan, 1998.

Surbakti, Ramlan. Memahami Ilmu Politik. Jakarta: PT. Gramedia Widiasarana Indonesia.

Sofyan, Ayi. Etika Politik Islam. Bandung: Pustaka Setia, 2012.

Syafii Ma'arif, Ahmad. Teori Belah Bambu Masa Demokrasi Terpimpin (1959-1965). Jakarta: Gema Insani Press, 1996.

,Islam Dalam Bingkai Keindonesiaan dan Kemanusiaan. Bandung: Mizan, 2009.

,Islam ditinjau dari berbagai aspek Jilid II. Jakarta: UI-Press, 2013.

Kapita Selekta Pendidikan Islam, Bandung: Angkasa, 2003.

Syafi'i Anwar, M. Pemikiran dan Aksi Islam Indonesia; Sebuah Kajian Politik tentang cendekiawan muslim orde baru. Jakarta: Paramadina, 1995.

Rahim, Husni, Madrasah Dalam Politik Pendidikan Islam, Jakarta: Logos Wacana Ilmu, 2005.

Rais, M. Dhiauddin. Teori Politik Islam. Jakarta: Gema Insani Press, 2011.

Wahid, Marzuki dan Rumadi Fikih Madjhab Negara: Kritik atas politik hukum Islam di Indonesia. Yogyakarta: Lkis, 2011.

W. Hefner, Robert. Civil Islam; Islam dan Demokratisasi di Indonesia, Yogyakarta: ISAI, 2001.

Yunus, Mahmud, Sejarah Pendidikan Islam di Indonesia, Jakarta: PT

Mahmud Yunus, cetakan ketiga 2008.

http://pendis.kemenag.go.id/

http://depag.go.id/ 